\title{
Performance Analysis of Photovoltaic Panels with Earth Water Heat Exchanger Cooling
}

\author{
Sanjeev Jakhar ${ }^{1, a}$, M.S. Soni ${ }^{1}$ and Nikhil Gakkhar ${ }^{1}$ \\ ${ }^{1}$ Center for Renewable Energy and Environment Development (CREED), Department of Mechanical Engineering, \\ Birla Institute of Technology and Science, Pilani, Rajasthan, India 333031
}

\begin{abstract}
The operating temperature is an important factor affecting the performance and life span of the Photovoltaic (PV) panels. The rising temperature can be maintained within certain limit using proper cooling techniques. In the present research a novel system for cooling of PV panels named as Earth Water Heat Exchanger (EWHE) is proposed and modelled in transient analysis simulation tool (TRNSYS v17.0) for the conditions of Pilani, Rajasthan (India).The various parameters which include cell temperature, PV power output and cell efficiency are observed with respect to variation in mass flow rate of fluid. Simulation results of the system without cooling show that the maximum PV panel temperature reached up to $79.31{ }^{\circ} \mathrm{C}$ with electrical efficiency dropped to $9 \%$ during peak sunshine hour. On the other hand, when PV panels are coupled with EWHE system, the panel temperature drops to $46.29{ }^{\circ} \mathrm{C}$ with an efficiency improving to $11 \%$ for a mass flow rate of $0.022 \mathrm{~kg} / \mathrm{s}$. In the end the cooling potential of EWHE is found to be in direct correlation with mass flow rate. The proposed system is very useful for the arid regions of western India which are blessed with high solar insolation throughout the year.
\end{abstract}

\section{Introduction}

The solar energy is an abundant energy source which can be harnessed by PV system to produce electricity and is a commercially proven technology [1-2]. Out of total solar insolation, only 10-20\% is converted into electrical energy while the remaining solar radiation is either converted into heat or is reflected back [3]. Thus results in an increment in the PV cells operating temperature. The increase in the operating temperature of the cell beyond certain limit not only decreases the efficiency of the cell but also decreases the life span due to the thermo-mechanical stress involved [4-5]. It is reported in the literature [6] that drop in efficiency by $0.45 \%$ may occur with every degree rise in the cell operating temperature above a certain limit. Therefore, the temperature control by cooling of PV becomes important and crucial factor for its better performance [7]. From the past few years a significant amount of work has been done on different PV cooling techniques by many researchers. One of them is Photovoltaic/ Thermal (PV/T) cooling technology in which thermal collectors are attached with PV panels to produce both thermal and electrical energy.

Hegazy [8] presented four types of PV/T air system and measured their thermal and electrical performance. He concluded that PV between single pass channels consumed the least fan power.

\footnotetext{
${ }^{a}$ Corresponding author :sanjeev.jakhar@pilani.bits-pilani.ac.in, sanjeevj450@gmail.com 
Solanki et al. [9] developed a cost effective setup of PV/T air collector and tested for indoor conditions. They found the thermal and electrical efficiency as $42 \%$ and $8.4 \%$, respectively. Cuce and Cuce [10] have done a numerical and experimental analysis of silicon PV cells with air cooling in order to improve their thermodynamic parameters. Dubey and Tiwari [11] presented an integrated combined system of a PV/T (glass to glass type) solar water heater of capacity 200 lts. Their experimental results showed that the instantaneous efficiency of system increased from $33 \%$ to $64 \%$ due to increase in glazing area. Bilbao and Sproul [12] conducted an experimental study on PV/T water cooling system with an improvement the 5\% efficiency of the system. Ji et al.[13] presented a sensitivity analysis of a hybrid PV/T water heating system with natural circulation. Their results showed saving of around $65 \%$ of primary energy on the daily basis with a PV cell covering factor of 0.63 .

Literature also cites various other cooling techniques which are used for different thermal systems other than PV. One of them is geothermal cooling which works on the principle that at a depth of about $3.5 \mathrm{~m}$ or more, the soil temperature remains fairly constant throughout the year and is approximately equal to the average annual ambient air temperature [14]. Some researchers have used earth air tunnel heat exchanger and EWHE for air conditioning using air and water as a cooling medium respectively [15-18]. In the EWHE hot water is sent through the pipes which are buried at a certain depth below the ground, where the heat is transferred from the hot water to the earth resulting in decrease in the outlet temperature[19-20]. This system of cooling water using buried pipes may be used for various cooling applications of which PV may be one.

In this current research, EWHE is coupled with PV panels as a cooling technique. The modelling and simulation of such coupled system for the conditions of Pilani, Rajasthan, has been done on TRNSYS (v17.0) using its metrological data files. The main aim of this research is to estimate the cooling performance of EWHE when couples with PV panels. For the same, various performance parameters of system are identified which include PV panel temperature, electrical efficiency etc.

\section{Description of Proposed System}

The schematic diagram of proposed coupled system is shown in Fig. 1. It consists of a PV/T, EWHE, valves and pump connected in series. In the PV/T system copper tubes are bonded to an absorber plate which is fixed underneath the PV panels as shown in Fig.1 (b). The whole PV/T is enclosed in a casing and insulated from the sides and back. The back side of PV panel consists of copper tubes which carries water to take away the excess heat from the panel thus resulting in increase in its own temperature. The outlet of PV/T is connected to EWHE through pipes and valves. It comprises of 30 $\mathrm{m}$ long horizontal High Density Polyethylene (HDPE) pipe, buried in flat land with dry soil at a $3.5 \mathrm{~m}$ depth. In the EWHE, heat is transferred from hot water (PV/T outlet) to the soil. As a result, the water temperature at the outlet of EWHE is much lower than the ambient during peak summer period. The outlet from the EWHE is then sent back to PV/T inlet through copper tubes for cooling.

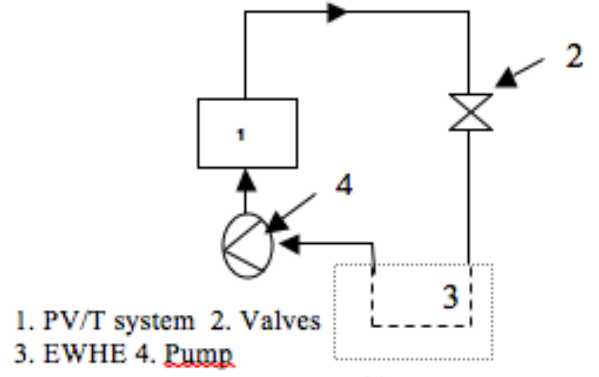

(a)

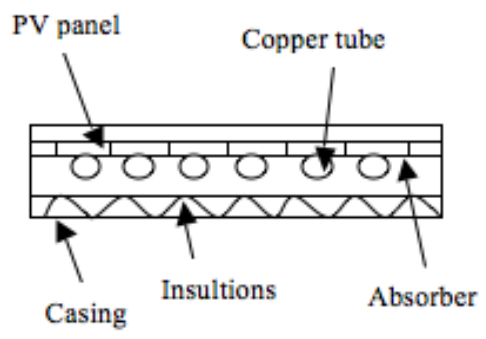

(b)

Figure 1. (a) Schematic Diagram of Proposed System (b) Cross-sectional of PV/T System.

\section{Modelling and Simulation}


The proposed system is modelled and simulated using TRNSYS software which is widely used for renewable energy system analysis [21]. Although its primary use is to model solar thermal applications, a number of attempts have been made to couple solar energy systems with other appliances. Here, a numerical simulation of the PV/T coupled with EWHE was carried out for a local weather condition using its inbuilt Meteonorm files. The model includes inbuilt components or Types, which can be interconnected through a flow chart, and takes parameters and time dependent inputs to give transient condition output. In the current system, the transient model for PV/T coupled with EWHE was used to estimate its performance over a particular time.

The following standard TRNSYS component models (Types) were used in the simulation:

-Type 560- PV/T collector

-Type 3- Variable speed pump

- Type 952- Earth water heat exchanger

-Type 15 - Weather data processor

-Type 65- Online plotter

-Type 28- Simulation summary

-Type 25- Printer

-Type 2 Controller

Type 560 is important model in electrical library of TRNSYS which supplied both electrical and thermal energy. Type 952 which is horizontal heat exchanger, interacts thermally with soil by considering conductive heat transfer and convective heat transfer within the pipes. The physical and thermal parameters used for the simulation, are shown in Table 1.

Table 1. Physical and Thermal Parameters Used in Simulation.

\begin{tabular}{|c|c|}
\hline Parameters & Properties \\
\hline PV/T collector length & $1.20 \mathrm{~m}$ \\
\hline PV/T collector width & $1.59 \mathrm{~m}$ \\
\hline $\begin{array}{c}\text { Thermal conductivity of absorber } \\
\text { plate }\end{array}$ & $385 \mathrm{~W} / \mathrm{m} \mathrm{K}$ \\
\hline Copper tube diameter (OD) & $0.012 \mathrm{~m}$ \\
\hline PV efficiency at reference condition & $12 \%$ \\
\hline PV panel reference temperature & $25^{\circ} \mathrm{C}$ \\
\hline HDPE pipe thermal conductivity & $0.40 \mathrm{~W} / \mathrm{m} \mathrm{K}$ \\
\hline Fluid density & $1000 \mathrm{~kg} / \mathrm{m}^{3}$ \\
\hline Fluid thermal conductivity & $0.55 \mathrm{~W} / \mathrm{m} \mathrm{K}$ \\
\hline
\end{tabular}

\section{Results and Discussion}

The performance of PV panel coupled with EWHE was analyzed by using TRNSYS (v17.0) for Pilani, Rajasthan (India). The simulation was conducted for 10 hours of system operation, which is average sunshine duration during peak (June 21) summer period. For the EWHE the performance of system was evaluated at the depth of $3.5 \mathrm{~m}$ where soil temperature remains almost constant throughout the year, while the length of pipe as considered $30 \mathrm{~m}$.

Fig. 2 shows the PV panel temperature variation without cooling or with cooling for different mass flow rates. PV temperature varies between $35.43{ }^{\circ} \mathrm{C}$ to $79.31{ }^{\circ} \mathrm{C}$ without cooling for 10 hours of system operation. It can be seen from the Fig. 2. that the PV panel temperature drops with the EWHE cooling and it ranges between $30.33-55.01{ }^{\circ} \mathrm{C}, 29.99-53.82^{\circ} \mathrm{C}, 28.40-44.71{ }^{\circ} \mathrm{C}$ and $28.33-46.29{ }^{\circ} \mathrm{C}$ for $0.006 \mathrm{~kg} / \mathrm{s}, 0.01 \mathrm{~kg} / \mathrm{s}, 0.022 \mathrm{~kg} / \mathrm{s}$ and $0.026 \mathrm{~kg} / \mathrm{s}$ flow rates respectively. It is also observed that the temperature remains almost constant for $0.018 \mathrm{~kg} / \mathrm{s}, 0.022 \mathrm{~kg} / \mathrm{s}$ and $0.026 \mathrm{~kg} / \mathrm{s}$ flow rates. 


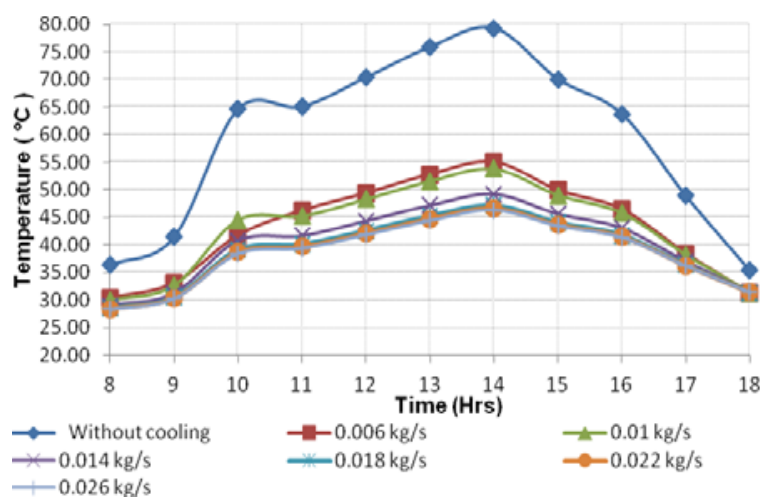

Figure 2. PV Panel Temperature Without Cooling and with Cooling for Different Mass Flow Rates.

Fig. 3 reveals the PV power output for different mass flow rates. The PV power over 10 hours remains within the range of $39.4 \mathrm{~W}$ to $140.3 \mathrm{~W}$ without cooling. While it varies from $38.3 \mathrm{~W}$ to $164.23 \mathrm{~W}$ with cooling for $0.026 \mathrm{~kg} / \mathrm{s}$ flow rate. It can be observed that the PV power increased by $23.93 \mathrm{~W}$ with EWHE cooling for same mass flow rate as compared to without cooling.

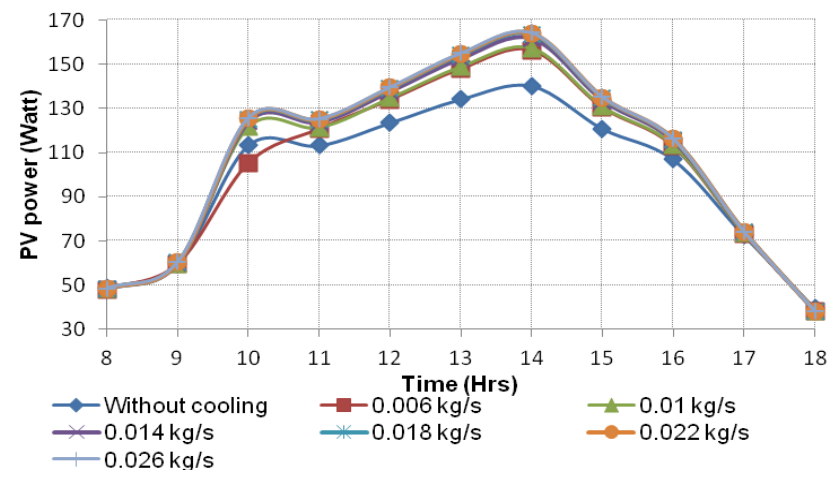

Figure 3. PV Power Output Without Cooling and with Cooling for Different Mass Flow Rates.

The simulated results of PV electrical efficiency for both configurations (without cooling and with cooling) at various flow rates have been shown in Fig. 4. In case of without cooling, the electrical efficiency was $9 \%$ for most of the time due to high cell temperature. Further with EWHE the efficiency is maintained at $11 \%$ for $0.022 \mathrm{~kg} / \mathrm{s}$ and $0.026 \mathrm{~kg} / \mathrm{s}$ flow rates. It can be concluded that the electrical efficiency of system is increased by $2 \%$ for $0.022 \mathrm{~kg} / \mathrm{s}$ and $0.026 \mathrm{~kg} / \mathrm{s}$, while it increases by $1 \%$ for $0.006 \mathrm{~kg} / \mathrm{s}$ and $0.01 \mathrm{~kg} / \mathrm{s}$ flow rates as compared to without cooling.

The cooling potential $(\mathrm{kWh})$ of the EWHE for different flow rates is shown in Fig. 5 and was calculated by using following equation.

$$
Q_{c}=\dot{m} C_{w} \Delta T
$$

where $\dot{m}$ is the mass flow rate of water in $\mathrm{kg} / \mathrm{s}, \mathrm{C}_{\mathrm{w}}$ is the specific heat of water in $\mathrm{kJ} / \mathrm{kg} \mathrm{K}$ and $\Delta \mathrm{T}$ is the temperature difference between inlet and outlet of EWHE. The cooling potential calculated after 6 hour operations are $2038.9 \mathrm{kWh}$ for $0.006 \mathrm{~kg} / \mathrm{s}$ and $3503.3 \mathrm{kWh}$ for $0.022 \mathrm{~kg} / \mathrm{s}$. It reveals that with increase in mass flow rate the cooling potential of EWHE increases as expected. This proves that higher mass flow rates (up to $0.022 \mathrm{~kg} / \mathrm{s}$ ) are beneficial for EWHE when it is coupled to PV/T system. 


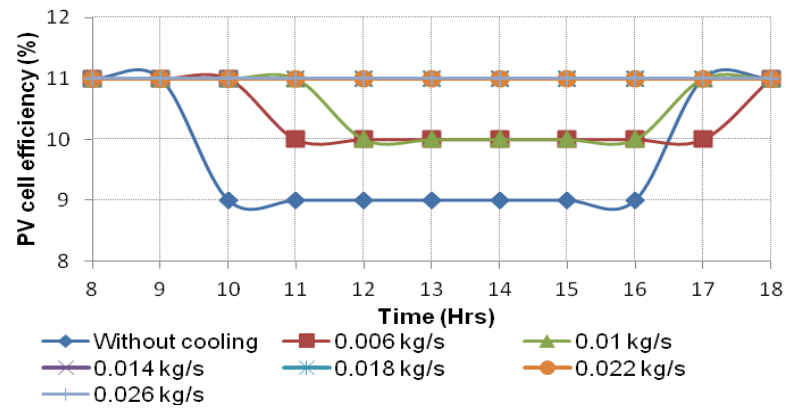

Figure 4. PV Electrical Efficiency Without Cooling and with Cooling for Different Mass Flow Rates.

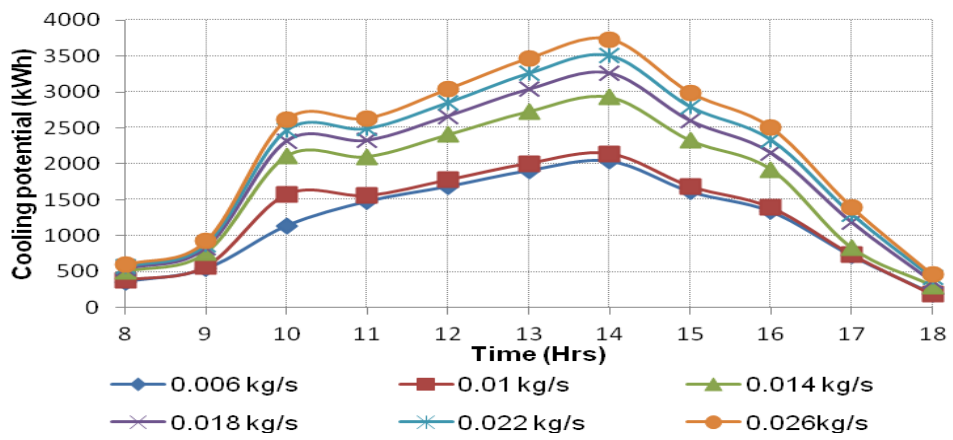

Figure 5. Cooling Potential of EWHE for Different Mass Flow Rates.

The EWHE system along with PV/T may be used for the arid regions of western Gujarat and Rajasthan (India) where solar irradiation is plenty and can be utilized by installing PV power plants. Such type of plants would provide electrical as well as thermal energy. This thermal energy may be dissipated with the help of an effective cooling system. Since, the ambient temperature of these regions goes up to $47{ }^{\circ} \mathrm{C}$ to $50^{\circ} \mathrm{C}$, leaving very small scope for utilization of thermal energy. While rejecting heat to the ambient will also be great challenge. Thus, EWHE will be better solution under such climatic conditions to achieve better performance of PV systems.

\section{Conclusion}

In the present paper an integrated system (EWHE and PV/T) has been simulated using transient simulation tool (TRNSYS v17.0) for local weather conditions of Pilani, Rajasthan. In the analysis the burial depth for EWHE as taken $3.5 \mathrm{~m}$ while the length of pipe as considered $30 \mathrm{~m}$. Results show that the maximum panel temperature dropped significantly from $79.31{ }^{\circ} \mathrm{C}$ to $46.29{ }^{\circ} \mathrm{C}$ for mass flow rate of $0.022 \mathrm{~kg} / \mathrm{s}$ when it is operated with EWHE. The electrical conversion efficiency of PV/T panel was increased by $2 \%$ when it is coupled with EWHE. The maximum power output from PV was found to be $140.3 \mathrm{~W}$ without cooling, while with cooling it is increased to $163.94 \mathrm{~W}$ for $0.026 \mathrm{~kg} / \mathrm{s}$ flow rate. It is observed that for 6 hours of operation of system, the cooling capacity of EWHE increases from $2038.9 \mathrm{kWh}$ to $3732.8 \mathrm{kWh}$ as mass flow rate increased from $0.006 \mathrm{~kg} / \mathrm{s}$ to $0.022 \mathrm{~kg} / \mathrm{s}$ respectively. Simulation results of the study confirmed that the EWHE system with PV/T is quite effective for PV cooling during summer season as it increases the electrical efficiency up to $11 \%$.

\section{References}

1. M.S Soni, N. Gakkhar, Renew Sustain Energy Rev., 40, 326-334 (2014)

2. A. Ummadisingu, M.S Soni, Renew Sustain Energy Rev., 15, 5169-5175 (2011)

3. M.Ozgoren, M.H. Aksoy, C. Bakir, S. EPJ Web Conferences, 45, 01106 (2013) 
4. A. Royne, C. J. Dey, D. R. Mills, Sol Energy Mater Sol Cells, 86, 451-483 (2005)

5. S. Jakhar, M.S Soni, N. Gakkhar, Renew Sustain Energy Rev., 60, 41-59 (2016)

6. D. Du, J. Darkwa, G. Kokogiannakis, Sol Energy, 97, 238-254 (2013)

7. P. S. Raj, M.S Soni, S. Jakhar, Proceedings of the International Congress on Renewable Energy, "Powering National Growth Through Solar", (ICORE), 282-289 (2014)

8. A. A. Hegazy, Energy Convers Manag, 41, 861-881 (2000)

9. S.C. Solanki, S. Dubey, A. Tiwari, Appl Energy, 86, 2421-248 (2009)

10. E. Cuce, P.M. Cuce, Int J Ambient Energy, 1-7 (2013)

11. S. Dubey, G.N. Tiwari, Sol Energy, 82, 602-612. (2008)

12. J.I Bilbao, A.B. Sproul, Proceeding of the 50th Annual conference, Austrailian Solar Energy Society, 1-11(2012)

13. J. Ji, J.P. Lu. T.T. Chow, W. He, G. Pei, Appl Energy, 84, 222-237 (2007)

14. Handbook, A.S.H.R.A.E., Fundamentals. American Society of Heating, Refrigerating and Air Conditioning Engineers Inc., NE Atlanta, GA 30329 ( 2009)

15. M.S. Sodha, A.K. Sharma, S.P. Singh, N.K. Bansal, A Kumar, Build Environ, 20, 115-122 (1985)

16. F.A. Ajmi, D.L. Loveday, V.I. Hanby, Build Environ, 41, 235-244 (2006)

17. V. Bansal, R. Misra, G. D. Agrawal, J. Mathur, Energy Build, 42, 645-648 (2010)

18. S. Jakhar, R. Misra, V. Bansal, M.S. Soni, Energy Build, 87, 360-369 (2015)

19. S. Jakhar, R. Misra, M.S. Soni, N. Gakkhar, Parametric simulation and experimental analysis of earth air heat exchanger with solar air heating duct, Engineering Science and Technology, an International Journal (2016), doi: 10.1016/j.jestch.2016.01.009

20. C.T. Joen, L. Liu, M.D. Paepe, Proceeding of International Refrigeration. Air Conditioning. Conf. Purdue Univ., 2194-2204 (2012).

21. TRNSYS 17: Transient System Simulation Program, University of Wisconsin, Madison (USA): Solar Energy Laboratory. 